УДК 342.25

DOI https://doi.org/10.32837/pyuv.v0i4.616

B. P. Hecmop

orcid.org/0000-0002-8194-1392

кандидат юридичних наук

\title{
МІСЬКЕ САМОВРЯДУВАННЯ В УКРАЇНІ КІНЦЯ ХХ - ПОЧАТКУ ХХІ СТОЛІТЬ
}

Міське самоуправління в Україні має досить давні історичні коріння. Воно є важливим чинником подальшого вдосконалення самоуправління в цілому, а також життя територіальних громад міст. Адже більшість населення України проживає саме в містах.

У зв'язку із цим важливим практичним завданням є подальше вдосконалення системи міського самоврядування, а важливим теоретичним завданням - належне доктринальне забезпечення цього процесу.

В українській юридичній літературі питання історичного розвитку міського самоврядування розкривається як одно з найважливіших у низці монографічних праць як загального характеру (А.Т. Назарко, В.М. Шкабаро), так і спеціального характеру, тобто, присвячених окремим інститутам міського самоврядування (меру, міській раді, статутам територіальних громад міст тощо). Майже недослідженими залишаються питання міського самоврядування в компаративному аспекті, виключення становлять лише окремі напрацювання Н.В. Мішиної $([1 ; 2 ; 3])$.

Метою статті $\epsilon$ аналіз становлення сучасного міського самоврядування в Україні наприкінці XX - на початку XXI століть.

Щодо України слід зазначити, що дійсно демократичне місцеве самоврядування почало формуватися лише наприкінці XX століття.

Значна кількість дослідників зверталась і продовжує звертатись до історичних питань, пов'язаних із появою та розвитком місцевого самоврядування в цілому й міського самоврядування зокрема. Не є винятком і місцеве самоврядування.

Незважаючи на те, що питання місцевого самоврядування знаходяться в полі зору досить давно, вони здебільшого досліджуються в цілому щодо рівня населених пунктів, або щодо рівня районів, областей. Привертає увагу, що в українській юридичній літературі досить небагато праць присвячено виключно міському самоврядуванню.

Традиційний підхід, відповідно до якого слід спочатку звернути увагу на історію досліджуваного інституту, а вже потім аналізувати сучасні проблеми й виклики сьогодення. У такому випадку дуже часто для їхнього подолання можна звернутися до національного історичного досвіду. Перевагами такого підходу буде, по-перше, те, що цей досвід вже апробовано саме в цій державі, а по-друге, - що є можливість ретельно перевірити всі переваги й недоліки такого досвіду. Звернення до національних нормативних документів, публікацій вітчизняних вчених, до матеріалів мас-медіа не є утрудненим ані з боку мовного бар'єра, ані з боку доступу до цих джерел інформації.

Відомий дослідник питань місцевого самоврядування в Україні професор О.В. Батанов узагальнив, що «в сучасній муніципально-правовій науці майже не викликає сумнівів, що інститут місцевого самоврядування тісно пов'язаний зі стародавнім громадським самоврядуванням i, по суті, генетично сходить до нього. У своєму історичному розвитку інститут місцевого самоврядування на європейському континенті пройшов такі етапи:

- етап полісної демократії (від VI століття до н.е. - до І століття до н.е.);

- римський етап (I століття н.е. - IV століття H.e.);

- етап самоорганізації (IV століття н.е. кінець XVIII століття);

- сучасний етап (з кінця XVIII століття до тепер)» $[4$, с. 248].

Професор О.В. Батанов, досліджуючи історію національного місцевого самоврядування, дійшов висновку, що «хронологічно початок становлення в Україні сучасної системи територіальної організації публічної влади пов'язується з 16 липням 1990 р. - днем ухвалення Декларації про державний суверенітет України. У цьому документі вперше за роки існування соціалістичної системи було проголошено відмову від радянської системи публічної влади, декларувався намір запровадити демократичні засади й принципи їі організації» [4, с. 272].

Автори одного 3 найпопулярніших підручників із муніципального права України висловлюють аналогічну думку. Вони узагальнили, що «початок реальному відродженню місцевого самоврядування в сучасних умовах поклали Декларація про державний суверенітет України й прийнятий на її основі й відповідно до неї Закон УРСР від 7 грудня 1990 р. «Про місцеві Ради народних депутатів Української РСР і місцеве самоврядування». Цей Закон вперше в умовах Союзу РСР і радянської влади проголошував принципи місцевого самоврядування та відмову від принципу "демократичного централізму» у відносинах між радами різних рівнів» [5, с. 21].

Декларація про державний суверенітет України від 16 липня 1990 р. не містила положень про 
місцеве самоврядування. В її положеннях згадувалися лише місцеві бюджети (в контексті податкових надходжень до них, Розділ VI «Економічна самостійність») і місцеві Ради Української РСР (у контексті того, що «Повновладдя народу України реалізується на основі Конституції Республіки як безпосередньо, так і через народних депутатів, обраних до Верховної та місцевих Рад Української PCP» [6]). Варто підкреслити, що в Декларації був Розділ III «Державна влада», однак розділу, присвяченого місцевому самоврядуванню повністю або частково, не було.

Закон Української РСР від 7 грудня 1990 р. «Про місцеві Ради народних депутатів Української РСР і місцеве самоврядування» неодноразово зазнавав змін і доповнень (у тому числі змінювалась і його назва) й був чинним до того, як набув юридичної сили чинний наразі Закон «Про місцеве самоврядування в Україні». Найтриваліший час Закон 1990 р. діяв під назвою «Про місцеві Ради народних депутатів і місцеве й регіональне самоврядування» - відповідні зміни було внесено 26 березня 1992 р., тоді ж Закон було викладено в новій редакції.

Закон 1990 р. у першій редакції передбачав, що:

«Місцеве самоврядування в Українській РСР це територіальна самоорганізація громадян для самостійного розв'язання безпосередньо або через державні й громадські органи, які вони обирають, усіх питань місцевого життя, виходячи з інтересів населення, на основі законів Української РСР і власної фінансово-економічної бази.

Територіальну основу місцевого самоврядування становлять сільрада, селище, район, місто, район у місті, область» [7].

Отже, самоуправління в містах почало реформуватися в напрямі його подальшої демократизації (саме такий напрям було запроваджено в СРСР рухом під назвою «перебудова»).

Приблизно через пів року після проголошення незалежності України Закон було викладено в новій редакції, а його назву - оновлено. 3 боку нашого дослідження вагоме те, що положення Закону були угруповані на ті, що мали відношення до місцевого самоврядування, та ті, що регламентували регіональне самоврядування. Самоуправління в містах охоплювалось поняттям «місцеве самоврядування». Відповідно до оновленого тексту Закону:

«місцеве самоврядування в Україні - це територіальна самоорганізація громадян для самостійного розв'язання безпосередньо або через органи, які вони обирають, усіх питань місцевого життя в межах Конституції України, законів України й власної фінансово-економічної бази.

Територіальну основу місцевого самоврядування становлять сільрада, селище, місто.

Органами місцевого самоврядування є сільські, селищні, міські Ради народних депутатів» [8].
В обох редакціях Закону 1990 р. не йшлося окремо про місцеве самоврядування в містах. Усі положення, які стосувались організації самоуправління в них, викладались спільно з аналогічними положеннями для деяких інших адміністративно-територіальних одиниць (наприклад, Глава 1 Розділу III «Державні органи місцевого самоврядування» охоплювала порядок формування, функції та загальну компетенцію всіх місцевих Рад народних депутатів тощо). Певним винятком були статті, які передбачали організацію місцевого самоврядування в районах у містах.

Цікавий той факт, що одним з основних принципів місцевого й регіонального самоврядування стаття 3 передбачала принцип «оптимальної децентралізації. У наступних кодифікованих законах про місцеве самоврядування він вже не згадувався, а до децентралізації публічної влади звернулись лише у $2014 \mathrm{p}$.

Ознайомлення з текстом обох редакцій Закону 1990 р. свідчить про те, що протягом його чинності відбувалися пошуки демократичної побудови системи місцевого самоврядування, яке було б відокремленим від органів державної влади. Вище було наведено назву одного з розділів цього Закону, в якій згадувались «державні органи місцевого самоврядування». Місцеве самоврядування поки що не розглядалось як прояв муніципальної влади - різновиду публічної влади.

Відповідно до законодавства, яке було чинним до прийняття Закону «Про місцеве самоврядування в Україні», місцеве самоврядування в містах було віднесено до базового рівня місцевого самоврядування. Система місцевого самоврядування передбачала наявність таких органів, які утворювались і функціонували в межах міст:

- міські й районні в містах Ради народних депутатів;

- органи територіального громадського самоврядування (будинкові, вуличні тощо комітети).

Також передбачалось створення виконавчих комітетів як міських, так і районних у містах Рад народних депутатів. Вони вважались виконавчими й розпорядчими органами Рад, які були підзвітні й підпорядковані відповідним Радам. у складі виконавчих комітетів діяли відділи й управління.

Отже, місцеве самоврядування з боку його організації в цілому й організаційно-правової форми зокрема зазнало лише незначних змін після прийняття Конституції України 1996 р. та оновлення кодифікованого закону про місцеве самоврядування. Найбільші зміни стосувались концептуального підходу до місця цього інституту в суспільстві починаючи з середини $1990-\mathrm{x} \mathrm{pp.} \mathrm{воно} \mathrm{більше} \mathrm{не}$ вважалось інститутом державної влади, а стало все частіше характеризуватися як інститут громадянського суспільства, функціонування якого 
гарантується державою. Більшість українських фахівців із муніципального права вважають, що публічна влада в Україні представлена двома різновидами: державною владою та місцевим самоврядуванням (муніципальною владою).

\section{Jimepamypa}

1. Мішина Н.В. Деякі особливості муніципального управління в Лондоні. Актуальні проблеми держави права : збірник наукових праць. Вип. 22. Одеса : Юридична література, 2004. С. 229-233.

2. Мішина Н.В. Органи самоорганізації населення в Україні: типологія та класифікація. Наукові праиі Наиіонального університету «Одеська юридична ака деміл». Том XX VI. Одеса, 2020. С. 81-89.

3. Мішина Н.В. Муніципальне управління в столиці Великобританії - Лондоні. Юридичний вісник. 2015. № 3. C. $260-265$.

4. Батанов О.В. Муніципальна влада в Україні: проблеми теорії та практики : монографія. Київ : Видавництво «Юридична думка», 2010. $656 \mathrm{c}$.

5. Погорілко В.Ф., Баймуратов М.О., Бальций Ю.Ю. та ін. Муніципальне право України : підручник. 2-ге вид.доп. Київ : Правова Єдність, 2009. 720 с.

6. Декларація про державний суверенітет України від 16 липня 1990 року № 55-XII. База даних «Законодавство України». URL: https://zakon.rada.gov.ua/ laws/show/55-12.

7. Про місцеві Ради народних депутатів Української РСР і місцеве самоврядування : Закон Української РСР від 7 грудня 1990 року № 533-XII. База даних «Законодавство України». URL: https://zakon.rada.gov.ua/laws/show/533-12.

8. Про місцеві Ради народних депутатів та місцеве і регіональне самоврядування : Закон України від 26 березня 1992 року № 2234-XII. База даних «Законодавство України». URL: https://zakon.rada.gov.ua/laws/ show/2234-12.

\section{Анотація}

Нестор В. Р. Міське самоврядування в Україні кінця XX - початку XXI століть. - Стаття.

Міське самоуправління в Україні має досить давні історичні коріння. Воно є важливим чинником подальшого удосконалення самоуправління в цілому, а також життя територіальних громад міст. Адже більшість населення України проживає саме в містах. Щодо України слід зазначити, що дійсно демократичне місцеве самоврядування почало формуватися лише наприкінці XX століття.

У зв'язку із цим важливим практичним завданням є подальше удосконалення системи міського самоврядування, а важливим теоретичним завданням - належне доктринальне забезпечення цього процесу.

Метою статті є аналіз становлення сучасного міського самоврядування в Україні наприкінці XX - на початку XXI століть.

Закон Української РСР від 7 грудня 1990 року «Про місцеві Ради народних депутатів Української РСР і місцеве самоврядування" неодноразово зазнавав змін i доповнень (у тому числі змінювалась $і$ його назва) й був чинним до того, як набув юридичної сили чинний наразі Закон «Про місцеве самоврядування в Україні» . Найтриваліший час Закон 1990 року діяв під назвою «Про місцеві Ради народних депутатів та місцеве і ре- гіональне самоврядування» - відповідні зміни було внесено 26 березня 1992 року, тоді ж Закон було викладено в новій редакції.

Місцеве самоврядування з боку його організації в цілому й організаційно-правової форми зокрема зазнало лише незначних змін після прийняття Конституції України 1996 року й оновлення кодифікованого закону про місцеве самоврядування. Найбільші зміни стосувались концептуального підходу до місця цього інституту в суспільстві - починаючи з середини 1990 -х років, воно більше не вважалось інститутом державної влади, а стало все частіше характеризуватися як інститут громадянського суспільства, функціонування якого гарантується державою. Більшість українських фахівців із муніципального права вважають, що публічна влада в Україні представлена двома різновидами: державною владою та місцевим самоврядуванням (муніципальною владою).

Ключові слова: міське самоврядування, місцеве самоврядування, місто, міська територіальна громада, територіальна громада, публічна влада.

\section{Summary}

Nestor V. R. City government in Ukraine at the end of the XX - beginning of the XXI centuries. - Article.

Municipal government in Ukraine has quite long historical roots. It is an important factor in further improving self-government in general, as well as the life of territorial communities of cities. After all, the majority of Ukraine's population lives in cities. As for Ukraine, it should be noted that truly democratic local self-government began to form only at the end of the twentieth century.

In this regard, an important practical task is to further improve the system of municipal self-government, and an important theoretical task is the proper doctrinal support of this process.

The aim of the article is to analyze the formation of modern urban self-government in Ukraine in the late XX - early XXI centuries.

The Law of the Ukrainian SSR of December 7, 1990 "On Local Councils of People's Deputies of the Ukrainian SSR and Local Self-Government" was repeatedly amended and supplemented (including its name), and was in force until the current Law "On Local Councils of People's Deputies of the Ukrainian SSR and Local Self-Government in Ukraine". For the longest time, the 1990 Law was entitled "On Local Councils of People's Deputies and Local and Regional Self-Government" - the relevant amendments were made on March 26, 1992, at which time the Law was reworded.

Local self-government in terms of its organization in general and organizational and legal form in particular has undergone only minor changes since the adoption of the Constitution of Ukraine in 1996 and the update of the codified law on local self-government. The biggest changes concerned the conceptual approach to the place of this institution in society - since the mid-1990s, it is no longer considered an institution of state power, but has become increasingly characterized as an institution of civil society, the functioning of which is guaranteed by the state. Most Ukrainian municipal law experts believe that public power in Ukraine is represented by two types: state power and local self-government (municipal power).

Key words: city government, local government, city, city territorial community, territorial community, public authority. 